\title{
Do National Cultures Impact Mortgage and Financial Well-Being Levels? Evidence from Europe
}

\author{
Rashed Isam Ashqar* iD, Júlio Lobão**
}

\begin{abstract}
This study explores the influence of national culture on mortgage and financial well-being levels in the European context. The paper employs regression analysis using mainly Hofstede's cultural dimensions and the EU-SILC dataset from Eurostat to provide a better understanding of the determinants of the decision to hold secured debts and a better explanation of the states of financial well-being. To the best of our knowledge, no study has addressed the influence of culture on mortgage and financial well-being levels in the European setting using samples from different countries and controlling for household characteristics. We conclude that power distance, masculinity, uncertainty avoidance, and long-term orientation are negatively associated with the likelihood of holding a mortgage. The results also show that masculinity, uncertainty avoidance, long-term orientation, and indulgence are negatively associated with the amount of mortgage. Moreover, individualism and long-term orientation (power distance and uncertainty avoidance) are positively (negatively) associated with being in a state of financial wellbeing. Collectively, our research shows that national cultures play a crucial role in household finance.
\end{abstract}

Keywords: culture; Hofstede dimensions; mortgage; financial well-being; Europe.

JEL classification: D10; G40; G51.

\section{INTRODUCTION}

The research on culture has been considered in the field of financial economics recently but still more limited, especially in the country-attributes or individual countries, without examining the household characteristics (Diez-Esteban et al., 2019; Gaganis et al., 2020). Hofstede (1983) defined culture as "the collective programming of mind" that leads to patterned ways of thinking, feeling, and acting, that differentiate the members of one nation, region, or group of people from others (p. 76). Also, a more recent definition for culture is "those customary beliefs and values that ethnic, religious, and social groups transmit fairly unchanged from generation to generation"(Guiso et al., 2006, p. 23). Kanagaretnam et al.

\footnotetext{
*University of Porto, Portugal; e-mail: ashqar.phd@fep.up.pt (corresponding author).

University of Porto, Portugal; e-mail: jlobao@fep.up.pt.
} 
(2015) indicated that culture includes many dimensions such as language, education, ethnic background, and religion.

Households use financial instruments in all stages of life. Moreover, nowadays the households are more directly engaged and more easily involved in complex financial decisions than in the past, due partly to financial innovation that led to extending the set of financing and investment choices available to households. Therefore, households should have certain know-how regarding payment choices, debt financing, saving, and insurance contracts (Guiso and Sodini, 2013). Social science has long been interested in the determinants of the financial well-being of individuals. However, past studies found a substantial cross-sectional variation that is not described by demographic or economic variables. Therefore, it is essential to better identify the source of individual variation in financial behavior and outcomes to better determine the extent of potential change by behavioral and policy interventions to enhance financial well-being ( $\mathrm{Xu}$ et al., 2015). To the best of our knowledge, there are no earlier studies that explored the effects of culture on a mortgage and financial well-being in the European setting using samples from different countries and using household characteristics. Therefore, this research seeks to fill that gap by investigating the influence of culture on the decision to hold secured debts and to be in a state of financial well-being in the European context.

Our research examines 31 European countries, and we hypothesize that power distance, long-term orientation, uncertainty avoidance will be negatively, and individualism and indulgence positively associated with the decision to hold secured debt. Also, we conjecture that individualism will be positively associated, whereas power distance, masculinity, and uncertainty avoidance will be negatively associated with financial well-being.

This study finds that power distance, masculinity, uncertainty avoidance, and long-term orientation (individualism and indulgence) are negatively (positively) associated with the likelihood of holding a mortgage. Masculinity, uncertainty avoidance, and indulgence (power distance, individualism, and long-term orientation) are positively (negatively) associated with the amount of mortgage. Furthermore, we discover that power distance and uncertainty avoidance (individualism and long-term orientation) are negatively (positively) associated with being in a state of financial well-being.

This paper is structured as follows. Section 2 presents and discusses the related literature review and develops the hypotheses to be tested. Section 3 describes the data and methodology. Section 4 reports and discusses the empirical results. Section 5 presents the discussions and Section 6 the main conclusions.

\section{LITERATURE REVIEW AND HYPOTHESES DEVELOPMENT}

\subsection{Literature Review}

Previous studies have explored the non-cultural determinants of mortgage levels and financial well-being levels. For example, Nyhus and Webley (2001) and S. Brown and Taylor (2014) examined the personality traits for the mortgage levels, while Donnelly et al. (2012) and Xu et al. (2015) investigated the personality traits for the financial well-being levels. Also, Wolswijk (2006) found that financial deregulation measures, stock market growth, house price, and after-tax mortgage interest costs are associated with real mortgage debt. Badev et al. (2014) found the GDP, policies connected with financial system development, the 
development of the insurance sector and the stock market, and sources of long-term funding are associated with the mortgage market development. In addition, Mahdzan et al. (2019) showed that financial behavior, locus of control, financial stress, and financial knowledge have a significant relationship with subjective financial well-being. Chatterjee et al. (2019) demonstrated that income security, unemployment, and overt materialism affect financial well-being.

Some studies have examined the influence of culture on household financial decisions. For example, Chang and Lin (2015) examined the national cultural factors that impact herding behavior, and they concluded that power distance, individualism, and masculinity have more dominant effects than others. Gogolin et al. (2017) focused on individual cultural values and demonstrated that self-expression values are positively associated with households' financial decisions. Besides, they showed that happiness, trust, and playing an active role in society are significant predictors of household financial decisions. M. Brown et al. (2018) concluded that financial socialization is an important driver of the cultural divide in financial literacy. Therefore, they found that students from the German-speaking area who receive pocket money at an early age and have independent access to a bank account are having a higher level of financial literacy than students in the French-speaking area. Fuseini et al. (2019) explored using Ghanaian data that culture largely shapes gender power relations in household decision-making and serves as the basis for justifying the status quo.

Other studies investigated the effects of culture on mortgage levels. For example, R. Aggarwal et al. (2012) found in foreign portfolio investment (FPI) destination countries that individualism, masculinity, and power distance are positively associated with debt and equity holdings by similar amounts. Whereas they found in FPI originating countries, the degree of masculinity positively impacts debt holdings more than twice as much as equity FPI, the degree of individualism positively impacts equity holdings almost three times as much as debt, and the degree of power distance has a greater effect on debt than equity holdings. Raj Aggarwal and Goodell (2014) discovered that masculinity and uncertainty avoidance are negatively associated with access to loan financing. Breuer et al. (2015) explored using survey data from 5912 economics university students in 45 countries that culture is a significant predictor of households' borrowing decisions. Additionally, they showed that the countries with high scores on long-term orientation are having shorter household debt maturity. Tajaddini and Hassan (2017) discovered that borrowers from societies with high individualism are more likely to have defaulted on their mortgages in both a relatively stable economic period and during a period of crisis. While they showed that borrowers from societies with low pragmatism and high indulgence default more on their mortgages in a stable economic period. Also, Rodriguez-Planas (2018) found that social norms in the country of ancestry are a significant predictor of determining immigrants' mortgage finance in the host country. Moreover, he found cultural attitudes regarding property rights are most important for explaining individuals' decisions to get a mortgage. However, those regarding credit information matter most to explain the amount of mortgage debt. In the recent study, Gaganis et al. (2020) found using cross-country data from 30 countries during 2001-2015, the national culture dimensions and interpersonal trust are significant determinants of the measurements of the housing mortgage such as mortgage depth, mortgage density, mortgage penetration, and mortgage affordability. Specifically, Gaganis et al. (2020) demonstrated that power distance, uncertainty avoidance, and long-term orientation are negatively associated, while 
individualism and indulgence are positively associated with mortgage debt. However, they did not find relationship between masculinity and mortgage debt.

Other studies explored the impacts of culture on financial and subjective well-being (SWB). For example, Arrindell et al. (1997); Arrindell (1998) observed the poorer countries that are more masculine were more likely to experience higher well-being. Hofstede (2001) and Hofstede $e t a l$. (2005) showed that uncertainty avoidance culture is negatively associated with well-being, they also found a higher percentage of the population claim to be unhappy in the societies that have high uncertainty avoidance. Ahuvia (2002) observed that people in individualistic countries tend to be happier than people living in collectivist societies. Diener et al. (2003) discovered that cultural variables clarify differences in mean levels of SWB, and they found culture can moderate which variables most influence SWB. Diener et al. (2009) concluded that individualism is positively associated with well-being across 55 countries. Fischer and Boer (2011) indicated that individualism is a better determinant of well-being than wealth, largely because it better enables to increase autonomy. Fazli Sabri et al. (2012) showed the childhood consumer experiences such as savings habits contribute to students' financial well-being. They also found the financial socialization through parents and religious sources might raise students' financial well-being. In a meta-analysis, Steel et al. (2018) observed an important role for the moderating effect such as wealth for the positive relationship between Individualism and SWB. They also suggested that power distance's relationship with SWB should be mediated by a combination of GDP per capita and governance. Additionally, they predicted that uncertainty avoidance and masculinity are negatively associated with SWB.

\subsection{Hypotheses Development}

In this study, we use the Hofstede (2011) model of national culture which includes six dimensions as following (Power Distance Index, Individualism versus Collectivism, Masculinity versus Femininity, Uncertainty Avoidance Index, Long-Term Orientation versus Short Term Orientation, and Indulgence versus Restraint). We also consider two types of household financial decisions: first, the decision to hold secured debt based on S. Brown et al. $(2008,2013)$ and S. Brown and Taylor (2014) through holding a mortgage that measured as a binary variable takes the value of 1 if the individual is holding a mortgage, otherwise, the value is 0 ; and log of the total mortgage ${ }^{1}$ calculated as the logarithm of mortgage principal repayment plus interest mortgage in Euro currency. Second, financial well-being is measured as the ability to make ends meet which takes the values as follows (ordinal variable): 1: with great difficulty, 2: with difficulty, 3: with some difficulty, 4: fairly easily, 5 : easily, 6: very easily; and the capacity to afford to pay a one-week annual holiday away from home as measured as a binary variable which takes the value of 1 if the answer yes, and 0 if it is no.

Individualism pertains to societies in which the ties between individuals are loose: everyone is expected to look after himself or herself and his or her immediate family. In contrast, collectivism pertains to societies in which people from birth onward are integrated into strong and cohesive in-groups, which throughout people's lifetimes continue to protect them in exchange for unquestioning loyalty (Hofstede et al., 2005). Therefore, the decisions of the individuals in individualistic societies are more independent and autonomous that lead them to hold secured debt more than others. Especially, that in individualist cultures that supposed the children to move out of their parent's home and live on their own when they start 
higher education (Hofstede et al., 2005). Breuer et al. (2014) found the individualism is positively associated with financial risk-taking. Chang and Lin (2015) showed that individualism is positively associated with herding behavior. Chui et al. (2016) observed the positive relationship between individualism and the cost of debt. Gaganis et al. (2020) found that individualism is positively associated with mortgage debt. Therefore, we predict,

Hypothesis 1: There is a positive relationship between individualism and the likelihood to hold debt.

The masculinity versus femininity dimension refers to the distribution of emotional roles between the genders (Hofstede, 2011). The masculine side represents a preference in society for achievement, heroism, assertiveness, and material rewards for success. Society at large is more competitive. Femininity as its opposite stands for a preference for cooperation, modesty, caring for the weak, and quality of life. Society at large is more consensus-oriented. Hofstede et al. (2005) indicated that status purchases are in general more frequent in masculine cultures, whereas feminine cultures spend more on products for the home. Raj Aggarwal and Goodell (2014) explored that masculinity is negatively associated with access to loan financing. Gaganis et al. (2020) found no relationship between masculinity and mortgage debt. We expect that masculine peoples are willing to have a higher amount of mortgage for their symbol of status to finance buying an expensive house.

Hypothesis 2: There is a positive relationship between masculinity and the likelihood to hold debt.

The Power Distance Index presents the degree to which the less powerful members of a society accept and expect that power is distributed unequally (Hofstede, 2011). Christen and Morgan (2005) found that income inequality is positively associated with all components of total household debt such as mortgage debt, credit card debt, and car loans. They also showed that rising income inequality has forced households with smaller income gains to using debt to keep up their consumption level more than households with larger income gains. Chang and Lin (2015) showed that power distance is negatively associated with herding behavior. Fligstein et al. (2017) found in the areas where income inequality was higher, all movers went deeper into debt and increased their monthly housing costs to live in more desirable neighborhoods. The richer people were able to take on less debt to keep their position in the status queue, while other people who made a move to buy a house took on more debt to keep up and maintain their social status and lifestyle. Gaganis et al. (2020) found that power distance is negatively associated with mortgage debt. Thus, the society members with less power distance that are equals and more likely to hold mortgage with higher amount.

Hypothesis 3: There is a negative relationship between power distance and the likelihood to hold debt.

Long-Term Orientation versus Short-Term Orientation relates to the choice of focus for people's efforts: the future or the present and past (Hofstede, 2011). Societies with a score low on this dimension show a preference to maintain time-honored traditions and norms, and they view societal change with suspicion. Whilst societies with a high score take a more pragmatic approach; they encourage thrift and efforts in modern education to prepare for the future. Long-term orientated cultures are cash or debit card cultures, not credit card cultures (de Mooij and Hofstede, 2002), and they have large savings quotes and funds available for investments (Hofstede et al., 2005). Breuer et al. (2015) discovered that countries with higher 
scores on long-term orientation led to having shorter household debt maturity. Gaganis et al. (2020) found that long-term orientation is negatively associated with mortgage debt. Hence, we expect,

Hypothesis 4: There is a negative relationship between long-term orientation and the likelihood to hold debt.

Uncertainty Avoidance Index expresses the degree to which the members of a society feel uncomfortable with unknown situations and ambiguity (Hofstede et al., 2005). This dimension is related to the view of society in dealing with the unknown future. Societies with high uncertainty avoidance take fewer risks and more worries about money when it comes to financial matters (Hofstede et al., 2005). Raj Aggarwal and Goodell (2014) discovered that uncertainty avoidance is negatively associated with access to loan financing. Gaganis et al. (2020) found that uncertainty avoidance is negatively associated with mortgage debt. Hence, we expect,

Hypothesis 5: There is a negative relationship between uncertainty avoidance and the likelihood to hold debt.

Indulgence versus Restraint relates to the gratification versus control of basic human desires related to enjoying life (Hofstede, 2011). Indulgenced societies are characterized by relatively free gratification of basic and natural human drives related to enjoying life and having fun. In contrast, restrained societies suppress the gratification of needs and regulate them using strict social norms. Penaloza and Barnhart (2011) explored that indulgence in expending relatively high levels of credit relative to their resources in pursuing their desires and pleasures. Gaganis et al. (2020) found that indulgence is positively associated with mortgage debt. Thus, we expect,

Hypothesis 6: There is a positive relationship between indulgence and the likelihood to hold debt.

Ahuvia (2002) observed that people in individualistic countries tend to be happier than people living in collectivist societies. Diener et al. (2009) reported that individualism is positively correlated with well-being across 55 nations. Fischer and Boer (2011) found that individualism is a better determinant of well-being than wealth, largely because it better enables to increase autonomy. Steel et al. (2018) showed the negative significant influence of individualism on life, family, and job satisfaction at the individual level. While at the national level, they observed an important role for the moderating effect such as wealth for the positive relationship between Individualism and SWB. Therefore, we expect,

Hypothesis 7: There is a positive relationship between individualism and the likelihood of being in a state of financial well-being.

Oishi et al. (2011) reported that inequality promotes feelings of injustice or envy and erodes trust and belongingness. Steel et al. (2018) suggested that power distance's relationship with SWB should be mediated by a combination of GDP per capita and governance. Hence, they discovered the power distance can make lower SWB. We expect that the societies that accept the inequality are less likely to experience financial well-being because the wealth and money will be limited to the small group in the society. Accordingly, we predict,

Hypothesis 8: There is a negative relationship between power distance and the likelihood of being in a state of financial well-being. 
Arrindell et al. (1997); Arrindell (1998) discovered the poorer countries that are more masculine were more likely to experience higher well-being. In contrast to the richer countries that are more feminine were associated with more well-being. Steel et al. (2018) predicted that masculinity is negatively associated with SWB. As masculine societies are not preferencing the quality of life, we expect they are less likely to experience financial wellbeing. Accordingly, we predict,

Hypothesis 9: There is a negative relationship between uncertainty avoidance and the likelihood of being in a state of financial well-being.

Hofstede (2001) and Hofstede et al. (2005) discovered that uncertainty avoidance culture is negatively associated with well-being, they also found a higher percentage of the population claim to be unhappy in the societies that have high uncertainty avoidance. Steel et al. (2018) predicted that uncertainty avoidance is negatively associated with SWB. Therefore, we expect,

Hypothesis 10: There is a negative relationship between masculinity and the likelihood of being in a state of financial well-being.

To the best of our knowledge, there is no evidence regarding the influence of long-term orientation and indulgence on financial well-being. However, we examined these two dismissions to find new evidence.

Wolswijk (2006) found that financial deregulation measures, stock market growth, and house price increases are positively associated with real mortgage debt, while after-tax mortgage interest costs were negatively associated. Badev et al. (2014) found the high levels of GDP, policies connected with financial system development such as (price stability and the efficiency of contractual and information frameworks), the development of the insurance sector and the stock market, and sources of long-term funding are associated with the mortgage market development. Therefore, following the existing literature (e.g., Wolswijk, 2006; Badev et al., 2014; Gaganis et al., 2020), we control our results of mortgage levels for different country-specific attributes such as inflation, urban population, GDP growth, dummy for Loan-to-Value (LTV) ratio, nominal house price indices, interest rates, tax property, bank concentration, and construction permits. Also, we control our results of financial well-being based on Steel et al. (2018) for GDP growth, income, and governance effectiveness.

\section{DATA AND METHODOLOGY}

\subsection{Data}

To examine the influence of culture on a mortgage and financial well-being, we used data from the European Union Statistics on Income and Living Conditions (EU-SILC) dataset, from the Eurostat database (See Annex 1). This data covers the households' interviews about their financial decisions from 2004 to 2018 for 31 European countries, including 26 member countries of the European Union (EU) and 5 other European countries ${ }^{2}$. Also, we obtained the cross-country data for six dimensions of national culture from Hofstede Insights. We collected urban population from World Development Indicators of the World Bank. In addition, data on inflation, interest rates, nominal house price indices, and GDP growth was gathered from European Mortgage Federation (EMF) Hypostat. We control for bank concentration from the Global Financial Development Database of the World Bank. Data on construction permits from 
the Doing Business Report of the World Bank. Data on tax property is from the Organization for Economic Co-Operation and Development (OECD). We used Corruption Perception Index (CPI) from Transparency International to measure governmental effectiveness. We also control the existence of a Loan-To-Value (LTV) macroprudential instrument from Cerutti et al. (2017).

Our data combines time series with cross-sectional data that allow the formation of panel data, the number of observations is 3,433,259, which included individuals aged 16 and above. As shown in Annex 2, the lowest number of observations in our sample correspond to Serbia and Iceland, with 34,265 observations and 38,250 observations, respectively, while the highest number of observations are from Spain and Italy, with 196,498 observations and 309,187 observations, respectively.

\subsection{Methodology}

National culture is measured using six Hofstede cultural dimensions: power distance (PD), individualism (IND), masculinity (MAS), uncertainty avoidance (UA), long-term orientation (LTO), and indulgence (INDUL). These variables have been expressed on a scale that runs from 0 to 100, with higher scores indicating a greater influence of a certain variable in a certain country. Summary statistics for the dependent, independent, and control variables are presented in Table no. 1.

Table no. 1 - Summary statistics

\begin{tabular}{lrrrrrrr}
\hline \multicolumn{1}{c}{ Variable } & Mean & Median & S.D & Min & Max & Skewness & Kurtosis \\
\hline Dependent Variables & & & & & & & \\
\hline Holding mortgage & 0.20 & 0.00 & 0.40 & 0.00 & 1.00 & 1.54 & 0.37 \\
\hline Log of total mortgage & 6.93 & 7.05 & 1.33 & 0.02 & 13.04 & -0.58 & 0.56 \\
\hline Ability to make ends meet & 3.33 & 3.00 & 1.36 & 1.00 & 6.00 & 0.04 & -0.68 \\
\hline $\begin{array}{l}\text { Capacity affords to pay for a one- } \\
\text { week annual holiday }\end{array}$ & 0.64 & 1.00 & 0.48 & 0.00 & 1.00 & -0.56 & -1.68 \\
\hline Independent Variables & & & & & & & \\
\hline PD & 50.28 & 50.00 & 18.75 & 11.00 & 100.00 & 0.35 & -0.08 \\
\hline IND & 60.50 & 63.00 & 17.92 & 17.00 & 89.00 & -0.84 & -0.08 \\
\hline MAS & 47.33 & 47.00 & 23.96 & 5.00 & 100.00 & -0.07 & -0.88 \\
\hline UA & 70.91 & 75.00 & 20.40 & 23.00 & 100.00 & -0.59 & -0.49 \\
\hline LTO & 56.32 & 58.00 & 15.95 & 24.00 & 83.00 & -0.04 & -0.81 \\
\hline INDUL & 44.34 & 44.00 & 17.66 & 13.00 & 78.00 & 0.07 & -1.12 \\
\hline Control Variables & & & & & & & \\
\hline GDP & 0.00 & -0.46 & 1.00 & -0.81 & 3.33 & 1.47 & 1.15 \\
\hline Inflation & 3.04 & 2.87 & 7.89 & -37.20 & 49.50 & 0.46 & 4.66 \\
\hline Interest rates & 3.81 & 3.49 & 1.86 & 0.81 & 13.15 & 1.56 & 3.70 \\
\hline House price & 101.02 & 100.00 & 17.29 & 41.75 & 166.43 & 0.23 & 1.55 \\
\hline Urbanization & 73.27 & 73.70 & 11.44 & 51.53 & 98.00 & -0.03 & -0.72 \\
\hline Bank concentration & 67.58 & 65.26 & 17.18 & 30.62 & 98.87 & -0.02 & -0.81 \\
\hline Construction permits & 14.10 & 14.00 & 4.09 & 7.00 & 24.00 & 0.28 & -0.72 \\
\hline Tax property & 1.76 & 1.43 & 1.17 & 0.22 & 17.37 & 2.61 & 27.12 \\
\hline CPI & 65.27 & 64.00 & 17.28 & 33.30 & 97.00 & 0.04 & -1.29 \\
\hline LTV & 0.34 & 0.00 & 0.47 & 0.00 & 1.00 & 0.67 & -1.56 \\
\hline Income & 0.00 & -0.26 & 1.00 & -25.98 & 332.36 & 46.50 & $10,432.07$ \\
\hline
\end{tabular}


Note: Data is panel data from 2004 to 2018 at individuals and household levels from EU-SILC's dataset. We standardized GDP and income using Z-score standardization. Log of total mortgage and income are expressed in Euro currency. Holding mortgage, and Log of total mortgage refer to the mortgage levels. Capacity affords to pay for a one-week annual holiday and the ability to make ends meet refer to financial well-being. Age is expressed in the number of years. Holding mortgage, Capacity affords to pay for a one-week annual holiday, and LTV are binary variables. Ability to make ends meet, PD, IND, MAS, UA, LTO, and INDUL are category variables. Log of total mortgage, GDP, Inflation, Interest rates, House price, Urbanization, Bank concentration, Construction permits, Tax property, CPI, and Income are continuous variables. (See Annex 3. Definitions of variables)

The correlation matrix for the national cultural indicators is shown in Annex 4. We show some of the correlations between the national cultural dimensions have moderate to high correlation coefficients. Such as, PD is positively correlated with UA (0.663), negatively correlated with IND (-0.556), and INDUL (-0.543), while the correlation between IND and UA is -0.559 , and between INDUL and UA is -0.508. (See Annex 4)

We estimate the appropriate panel data methodology for binary response models based on Wooldridge (2010). Therefore, we employ a logistic regression approach (Logit models) for all the binary dependent variables, that is, holding the mortgage and pay a one-week holiday. We used the ordinal logistic regression for the ability to make ends meet which is an ordinal variable. On the other hand, based on Gaganis et al. (2020), we used the estimation of the random effects for the log of the total mortgage that is a continuous variable. Besides, we address the endogeneity problem using a generalized method of moments (GMM) models based on Diez-Esteban et al. (2019). Additionally, following Gaganis et al. (2020), we introduce only one cultural dimension per regression to avoid the multicollinearity issues (See Annex 4), we also employ the baseline regression for the first model (Holding secured debt), where we control for inflation, urban population, and country. Moreover, we employ additional estimates while controlling for other country-specific attributes. Furthermore, following Steel et al. (2018), we control the second model (Financial well-being) for governance effectiveness, GDP, and income. The following two main models are used to test the research hypotheses:

Holding secured debt $=\beta_{0}+\beta_{1} \mathrm{PD}+\beta_{2}$ IND $+\beta_{3} \mathrm{MAS}+\beta_{4} \mathrm{UA}+\beta_{5} \mathrm{LTO}+\beta_{6}$ Indulgence + $\beta_{7}$ Inflation $+\beta_{8}$ Urbanization... (1)

Holding secured debt is measured based on two variables: holding the mortgage, and log of the total mortgage, hence, we have two regressions related to holding secured debt.

Financial well - being $=\beta_{0}+\beta_{1} \mathrm{PD}+\beta_{2} \mathrm{IND}+\beta_{3} \mathrm{MAS}+\beta_{4} \mathrm{UA}+\beta_{5} \mathrm{LTO}+\beta_{6}$ Indulgence + $\beta_{7}$ CPI $+\beta_{8}$ GDP $+\beta_{9}$ Income $\ldots$ (2)

Financial well-being is going to be proxied by two variables: the ability to make ends meet, and the capacity to afford to pay a one-week annual holiday away from home. Thus, we have two regressions related to financial well-being. 


\section{EMPIRICAL RESULTS}

\subsection{Analysis of the decision to hold secured debt}

Table no. 2 present the results of the baseline logistic regressions of the determinants of holding the mortgage, where we control for urbanization and inflation.

Table no. 2 - Culture and holding mortgage: Baseline model

\begin{tabular}{|c|c|c|c|c|c|c|}
\hline & (1) & (2) & (3) & (4) & (5) & (6) \\
\hline$\overline{\text { IND }}$ & $\begin{array}{r}0.011 * * * \\
(0.000)\end{array}$ & & & & & \\
\hline MAS & & $\begin{array}{r}-0.008 * * * \\
(0.000)\end{array}$ & & & & \\
\hline PD & & & $\begin{array}{r}-0.025^{* * *} * \\
(0.000)\end{array}$ & & & \\
\hline LTO & & & & $\begin{array}{r}-0.001 * * * \\
(0.000)\end{array}$ & & \\
\hline UA & & & & & $\begin{array}{r}-0.016^{* * * *} \\
(0.000)\end{array}$ & \\
\hline INDUL & & & & & & $\begin{array}{r}0.028 * * * * \\
(0.000)\end{array}$ \\
\hline Urbanization & $\begin{array}{r}0.051 * * * \\
(0.000)\end{array}$ & $\begin{array}{r}0.052 * * * \\
(0.000)\end{array}$ & $\begin{array}{r}0.048 * * * \\
(0.000)\end{array}$ & $\begin{array}{r}0.057 * * * \\
(0.000)\end{array}$ & $\begin{array}{r}0.050 * * * \\
(0.000)\end{array}$ & $\begin{array}{r}0.030 * * * \\
(0.000)\end{array}$ \\
\hline Inflation & $\begin{array}{r}-0.007 * * * \\
(0.000)\end{array}$ & $\begin{array}{r}-0.008 * * * \\
(0.000)\end{array}$ & $\begin{array}{r}-0.010 * * * * \\
(0.000)\end{array}$ & $\begin{array}{r}-0.007 * * * * \\
(0.000)\end{array}$ & $\begin{array}{r}-0.010 * * * * \\
(0.000)\end{array}$ & $\begin{array}{r}-0.008 * * * \\
(0.000)\end{array}$ \\
\hline (Intercept) & $\begin{array}{r}-5.995 * * * \\
(0.011) \\
\end{array}$ & $\begin{array}{r}-5.008 * * * \\
(0.013) \\
\end{array}$ & $\begin{array}{r}-3.922 * * * \\
(0.013) \\
\end{array}$ & $\begin{array}{r}-5.623 * * * \\
(0.011) \\
\end{array}$ & $\begin{array}{r}-4.115 * * * \\
(0.013) \\
\end{array}$ & $\begin{array}{r}-4.995 * * * \\
(0.011) \\
\end{array}$ \\
\hline Num. Obs. & $3,167,412$ & $3,167,412$ & $3,167,412$ & $3,167,412$ & $3,167,412$ & $3,167,412$ \\
\hline AIC & $2,930,830.0$ & 2928873.6 & $2,874,635.7$ & $2,940,187.2$ & $2,889,291.7$ & $2877,824.1$ \\
\hline BIC & $2,930,881.9$ & $2,928,925.4$ & $2,874,687.5$ & $2,940,239.1$ & $2,889,343.5$ & $2,877,876.0$ \\
\hline Log.Lik. & $-1,465,411.0$ & $-1,464,432.8$ & $-1,437,313.8$ & $-1,470,089.6$ & $-1,444,641.8$ & $-1,438,908.1$ \\
\hline
\end{tabular}

From Table no. 2, we found that power distance, masculinity, uncertainty avoidance, and long-term orientation are negatively associated with holding a mortgage and they are statistically significant at the $1 \%$ level. Results on these four dimensions mean that individuals are less likely to have a mortgage. In contrast to the individualism and indulgence that were positively associated with holding the mortgage and they are statistically significant at the $1 \%$ level. Regarding the control variables, we found the urban population positively associated with holding a mortgage, while inflation was negatively associated. Table no. 3 presents the estimations of holding the mortgage that includes all the control variables. 
Table no. 3 - Culture and holding mortgage: Inclusion of control variables

\begin{tabular}{|c|c|c|c|c|c|c|}
\hline & (1) & (2) & (3) & (4) & (5) & (6) \\
\hline$\overline{\text { IND }}$ & $\begin{array}{r}0.007 * * * \\
(0.000)\end{array}$ & & & & & \\
\hline MAS & & $\begin{array}{r}-0.001 * * * \\
(0.000)\end{array}$ & & & & \\
\hline PD & & & $\begin{array}{r}-0.013 * * * \\
(0.000)\end{array}$ & & & \\
\hline LTO & & & & $\begin{array}{r}-0.001 * * * \\
(0.000)\end{array}$ & & \\
\hline UA & & & & & $\begin{array}{r}-0.006 * * * \\
(0.000)\end{array}$ & \\
\hline INDUL & & & & & & $\begin{array}{r}0.029 * * * \\
(0.000)\end{array}$ \\
\hline Urbanization & $\begin{array}{r}0.046^{* * * *} \\
(0.000)\end{array}$ & $\begin{array}{r}0.049 * * * \\
(0.000)\end{array}$ & $\begin{array}{r}0.050 * * * \\
(0.000)\end{array}$ & $\begin{array}{r}0.048^{* * * *} \\
(0.000)\end{array}$ & $\begin{array}{r}0.050 * * * \\
(0.000)\end{array}$ & $\begin{array}{r}0.034 * * * \\
(0.000)\end{array}$ \\
\hline Inflation & $\begin{array}{r}-0.018 * * * \\
(0.000)\end{array}$ & $\begin{array}{r}-0.019 * * * \\
(0.000)\end{array}$ & $\begin{array}{r}-0.018 * * * \\
(0.000)\end{array}$ & $\begin{array}{r}-0.018 * * * \\
(0.000)\end{array}$ & $\begin{array}{r}-0.018 * * * \\
(0.000)\end{array}$ & $\begin{array}{r}-0.018 * * * \\
(0.000)\end{array}$ \\
\hline Interest rates & $\begin{array}{r}-0.064 * * * \\
(0.002)\end{array}$ & $\begin{array}{r}-0.045^{* * * *} \\
(0.002)\end{array}$ & $\begin{array}{r}-0.045^{* * * *} \\
(0.002)\end{array}$ & $\begin{array}{r}-0.048 * * * \\
(0.002)\end{array}$ & $\begin{array}{r}-0.047 * * * \\
(0.002)\end{array}$ & $\begin{array}{r}-0.029 * * * \\
(0.002)\end{array}$ \\
\hline House price & $\begin{array}{r}-0.004 * * * \\
(0.000)\end{array}$ & $\begin{array}{r}-0.005^{* * *} \\
(0.000)\end{array}$ & $\begin{array}{r}-0.002 * * * \\
(0.000)\end{array}$ & $\begin{array}{r}-0.005 * * * \\
(0.000)\end{array}$ & $\begin{array}{r}-0.003^{* * *} \\
(0.000)\end{array}$ & $\begin{array}{r}-0.005 * * * \\
(0.000)\end{array}$ \\
\hline $\begin{array}{l}\text { Construction } \\
\text { permits }\end{array}$ & $\begin{array}{r}-0.089 * * * \\
(0.001)\end{array}$ & $\begin{array}{r}-0.091 * * * \\
(0.001)\end{array}$ & $\begin{array}{r}-0.089 * * * \\
(0.001)\end{array}$ & $\begin{array}{r}-0.091 * * * \\
(0.001)\end{array}$ & $\begin{array}{r}-0.089 * * * \\
(0.001)\end{array}$ & $\begin{array}{r}-0.069 * * * \\
(0.001)\end{array}$ \\
\hline $\begin{array}{l}\text { Property } \\
\text { taxation }\end{array}$ & $\begin{array}{r}-0.238 * * * \\
(0.003)\end{array}$ & $\begin{array}{r}-0.214 * * * \\
(0.003)\end{array}$ & $\begin{array}{r}-0.172 * * * \\
(0.003)\end{array}$ & $\begin{array}{r}-0.205 * * * \\
(0.003)\end{array}$ & $\begin{array}{r}-0.221 * * * \\
(0.003)\end{array}$ & $\begin{array}{r}-0.350 * * * \\
(0.003)\end{array}$ \\
\hline $\begin{array}{l}\text { Bank } \\
\text { concentration }\end{array}$ & $\begin{array}{r}0.005 * * * \\
(0.000)\end{array}$ & $\begin{array}{r}0.004 * * * \\
(0.000)\end{array}$ & $\begin{array}{r}0.001 * * \\
(0.000)\end{array}$ & $\begin{array}{r}0.005 * * * \\
(0.000)\end{array}$ & $\begin{array}{r}0.001 * * * * \\
(0.000)\end{array}$ & $\begin{array}{r}-0.003 * * * \\
(0.000)\end{array}$ \\
\hline GDP & $\begin{array}{r}0.119 * * * \\
(0.003)\end{array}$ & $\begin{array}{r}0.132 * * * \\
(0.003)\end{array}$ & $\begin{array}{r}0.095 * * * \\
(0.003)\end{array}$ & $\begin{array}{r}0.139 * * * \\
(0.003)\end{array}$ & $\begin{array}{r}0.121 * * * \\
(0.003)\end{array}$ & $\begin{array}{r}0.237 * * * \\
(0.003)\end{array}$ \\
\hline LTV & $\begin{array}{r}0.264 * * * \\
(0.006)\end{array}$ & $\begin{array}{r}0.285 * * * \\
(0.006)\end{array}$ & $\begin{array}{r}0.273 * * * \\
(0.006)\end{array}$ & $\begin{array}{r}0.327 * * * \\
(0.006)\end{array}$ & $\begin{array}{r}0.258 * * * \\
(0.006)\end{array}$ & $\begin{array}{r}0.473 * * * \\
(0.006)\end{array}$ \\
\hline (Intercept) & $\begin{array}{r}-3.600 * * * \\
(0.033) \\
\end{array}$ & $\begin{array}{r}-3.289 * * * \\
(0.039) \\
\end{array}$ & $\begin{array}{r}-2.912 * * * \\
(0.032) \\
\end{array}$ & $\begin{array}{r}-3.243 * * * \\
(0.033) \\
\end{array}$ & $\begin{array}{r}-2.948 * * * \\
(0.034) \\
\end{array}$ & $\begin{array}{r}-3.328 * * * \\
(0.031) \\
\end{array}$ \\
\hline Num. Obs. & $1,401,831$ & $1,401,831$ & $1,401,831$ & $1,401,831$ & $1,401,831$ & $1,401,831$ \\
\hline AIC & $1,206,342.5$ & $1,207,043.9$ & $1,202,359.7$ & $1,206,467.0$ & $1,205,015.6$ & $1,181,622.4$ \\
\hline BIC & $1,206,476.2$ & $1,207,177.6$ & $1,202,493.4$ & $1,206,600.7$ & $1,205,149.3$ & $1,181,756.1$ \\
\hline Log.Lik. & $-603,160.2$ & $-603,510.9$ & $-601,168.8$ & $-603,222.5$ & $-602,496.8$ & $-590,800.2$ \\
\hline
\end{tabular}

The results show that even after controlling the variables the relationship between cultural dimensions and holding a mortgage is still strong with the same evidence of the baseline model (Table no. 2). Regarding the control variables, we found the interest rates, house price, construction permits, and property taxation are negatively associated with holding the mortgage, while bank concentration, GDP, and LTV were positively associated. We accept our hypotheses ( 1 and 3 to 6 ) related to the "decision to hold secured debt" that suggests that individualism and indulgence will be positive, while that power distance, 
uncertainty avoidance, and long-term orientation will be negative with the decision to hold secured debt. Also, we reject the hypothesis (2) that suggests there is a positive relationship between masculinity and the decision to hold secured debt, contrary to what we found a negative relationship between masculinity and holding a mortgage. Similarly, the findings of national culture are consistent with Gaganis et al. (2020), except for masculinity. Our result (A masculinity is negatively associated with holding the mortgage) contradicts other studies such as Gaganis et al. (2020) that suggest there is no relationship between masculinity and holding a mortgage. Moreover, the finding of long-term orientation corresponds with de Mooij and Hofstede (2002) that suggests that long-term orientated cultures are cash or debit card cultures, not credit card cultures. Table no. 4 presents the results of the baseline random effects estimation for the log of mortgage, where we control for urbanization and inflation.

Table no. 4 - Culture and log of mortgage: Baseline model

\begin{tabular}{|c|c|c|c|c|c|c|}
\hline & (1) & (2) & (3) & (4) & (5) & (6) \\
\hline$\overline{\text { IND }}$ & $\begin{array}{r}-0.010^{* * * *} \\
(0.000)\end{array}$ & & & & & \\
\hline MAS & & $\begin{array}{c}0.000^{*} \\
(0.000)\end{array}$ & & & & \\
\hline PD & & & $\begin{array}{r}-0.008 * * * \\
(0.000)\end{array}$ & & & \\
\hline LTO & & & & $\begin{array}{r}-0.021 * * * * \\
(0.000)\end{array}$ & & \\
\hline UA & & & & & $\begin{array}{r}0.001 * * * \\
(0.000)\end{array}$ & \\
\hline INDUL & & & & & & $\begin{array}{r}0.038 * * * \\
(0.000)\end{array}$ \\
\hline Urbanization & $\begin{array}{r}0.029 * * * \\
(0.000)\end{array}$ & $\begin{array}{r}0.022 * * * * \\
(0.000)\end{array}$ & $\begin{array}{r}0.020 * * * \\
(0.000)\end{array}$ & $\begin{array}{r}0.026 * * * \\
(0.000)\end{array}$ & $\begin{array}{r}0.022 * * * \\
(0.000)\end{array}$ & $\begin{array}{r}-0.011 * * * * \\
(0.000)\end{array}$ \\
\hline Inflation & $\begin{array}{r}-0.032 * * * * \\
(0.001)\end{array}$ & $\begin{array}{r}-0.032 * * * * \\
(0.001)\end{array}$ & $\begin{array}{r}-0.037 * * * * \\
(0.001)\end{array}$ & $\begin{array}{r}-0.032 * * * * \\
(0.001)\end{array}$ & $\begin{array}{r}-0.032 * * * \\
(0.001)\end{array}$ & $\begin{array}{r}-0.039 * * * * \\
(0.001)\end{array}$ \\
\hline (Intercept) & $\begin{array}{r}5.266^{* * * *} \\
(0.025) \\
\end{array}$ & $\begin{array}{r}5.085^{* * * *} \\
(0.030) \\
\end{array}$ & $\begin{array}{r}5.630 * * * \\
(0.029) \\
\end{array}$ & $\begin{array}{r}5.927 * * * \\
(0.026) \\
\end{array}$ & $\begin{array}{r}5.015^{* * *} \\
(0.030) \\
\end{array}$ & $\begin{array}{r}5.816^{* * * *} \\
(0.025) \\
\end{array}$ \\
\hline $\begin{array}{l}\text { Num. Obs. } \\
\text { R2 }\end{array}$ & $\begin{array}{r}374,446 \\
0.180\end{array}$ & $\begin{array}{r}374,446 \\
0.177\end{array}$ & $\begin{array}{r}374,446 \\
0.179\end{array}$ & $\begin{array}{r}374,446 \\
0.197\end{array}$ & $\begin{array}{r}374,446 \\
0.177\end{array}$ & $\begin{array}{r}374,446 \\
0.217\end{array}$ \\
\hline
\end{tabular}

Notes: This table reports the results of random effects models for the determinants of the log of mortgage on the list of national culture, urbanization, and inflation listed in the first column. Std. Error in parentheses. $* p<0.1, * * p<0.05, * * * p<0.01$. (See Annex 3. Definitions of variables)

The results show from Table no. 4, that masculinity, uncertainty avoidance, and indulgence are positively associated with the amount of mortgage and statistically significant at the $1 \%$ level (with exception of masculinity that is statistically significant at the $10 \%$ level). This means the individuals that having these cultural dimensions are more likely to pay a higher amount of mortgage. On the contrary, power distance, individualism, and long-term orientation were negatively associated with the amount of mortgage, and they are statistically significant at the $1 \%$ level. Regarding the control variables, we found the urban population positively associated with holding a mortgage, while inflation was negatively associated. Table no. 5 presents the estimations of the log of the mortgage that includes all the control variables. 
Table no. 5 - Culture and log of mortgage: Inclusion of control variables

\begin{tabular}{|c|c|c|c|c|c|c|}
\hline & (1) & (2) & (3) & (4) & (5) & (6) \\
\hline$\overline{\text { IND }}$ & $\begin{array}{r}-0.004 * * * \\
(0.001)\end{array}$ & & & & & \\
\hline MAS & & $\begin{array}{r}0.030 * * * \\
(0.000)\end{array}$ & & & & \\
\hline PD & & & $\begin{array}{r}-0.028 * * * \\
(0.001)\end{array}$ & & & \\
\hline LTO & & & & $\begin{array}{r}-0.063 * * * \\
(0.001)\end{array}$ & & \\
\hline UA & & & & & $\begin{array}{r}0.005 * * * \\
(0.000)\end{array}$ & \\
\hline INDUL & & & & & & $\begin{array}{r}0.062 * * * \\
(0.001)\end{array}$ \\
\hline Urbanization & $\begin{array}{r}-0.009 * * * \\
(0.001)\end{array}$ & $\begin{array}{r}0.009 * * * * \\
(0.001)\end{array}$ & $\begin{array}{r}-0.008 * * * \\
(0.001)\end{array}$ & $\begin{array}{r}0.034 * * * \\
(0.001)\end{array}$ & $\begin{array}{r}-0.011 * * * \\
(0.001)\end{array}$ & $\begin{array}{r}-0.045^{* * * *} \\
(0.001)\end{array}$ \\
\hline Inflation & $\begin{array}{r}-0.151^{* * *} \\
(0.001)\end{array}$ & $\begin{array}{r}-0.156^{* * * *} \\
(0.001)\end{array}$ & $\begin{array}{r}-0.152^{* * * *} \\
(0.001)\end{array}$ & $\begin{array}{r}-0.079^{* * *} \\
(0.001)\end{array}$ & $\begin{array}{r}-0.155^{* * * *} \\
(0.001)\end{array}$ & $\begin{array}{r}-0.117 * * * \\
(0.001)\end{array}$ \\
\hline Interest rates & $\begin{array}{r}-0.233 * * * \\
(0.005)\end{array}$ & $\begin{array}{r}-0.373 * * * \\
(0.005)\end{array}$ & $\begin{array}{r}-0.191 * * * \\
(0.005)\end{array}$ & $\begin{array}{r}-0.165 * * * \\
(0.005)\end{array}$ & $\begin{array}{r}-0.260 * * * \\
(0.005)\end{array}$ & $\begin{array}{r}-0.115 * * * \\
(0.005)\end{array}$ \\
\hline House price & $\begin{array}{r}0.032 * * * \\
(0.001)\end{array}$ & $\begin{array}{r}0.036 * * * \\
(0.001)\end{array}$ & $\begin{array}{r}0.050 * * * \\
(0.001)\end{array}$ & $\begin{array}{r}0.045 * * * \\
(0.001)\end{array}$ & $\begin{array}{r}0.028 * * * \\
(0.001)\end{array}$ & $\begin{array}{r}0.045^{* * * *} \\
(0.001)\end{array}$ \\
\hline $\begin{array}{l}\text { Construction } \\
\text { permits }\end{array}$ & $\begin{array}{r}0.103 * * * \\
(0.003)\end{array}$ & $\begin{array}{r}0.092^{* * * *} \\
(0.003)\end{array}$ & $\begin{array}{r}0.126 * * * \\
(0.003)\end{array}$ & $\begin{array}{r}-0.031 * * * \\
(0.003)\end{array}$ & $\begin{array}{r}0.099 * * * \\
(0.003)\end{array}$ & $\begin{array}{r}0.201 * * * \\
(0.003)\end{array}$ \\
\hline $\begin{array}{l}\text { Property } \\
\text { taxation }\end{array}$ & $\begin{array}{r}0.552 * * * \\
(0.011)\end{array}$ & $\begin{array}{r}0.455^{* * * *} \\
(0.010)\end{array}$ & $\begin{array}{r}0.628 * * * \\
(0.010)\end{array}$ & $\begin{array}{r}-0.179 * * * \\
(0.011)\end{array}$ & $\begin{array}{r}0.533 * * * \\
(0.010)\end{array}$ & $\begin{array}{r}0.357 * * * \\
(0.010)\end{array}$ \\
\hline $\begin{array}{l}\text { Bank } \\
\text { concentration }\end{array}$ & $\begin{array}{r}0.053 * * * \\
(0.001)\end{array}$ & $\begin{array}{r}0.065^{* * * *} \\
(0.001)\end{array}$ & $\begin{array}{r}0.051 * * * \\
(0.001)\end{array}$ & $\begin{array}{r}0.012 * * * \\
(0.001)\end{array}$ & $\begin{array}{r}0.054 * * * \\
(0.001)\end{array}$ & $\begin{array}{r}0.049 * * * \\
(0.001)\end{array}$ \\
\hline GDP & $\begin{array}{r}0.681 * * * \\
(0.009)\end{array}$ & $\begin{array}{r}0.496^{* * * *} \\
(0.009)\end{array}$ & $\begin{array}{r}0.616^{* * * *} \\
(0.009)\end{array}$ & $\begin{array}{r}0.805 * * * \\
(0.009)\end{array}$ & $\begin{array}{r}0.680 * * * \\
(0.009)\end{array}$ & $\begin{array}{r}0.936^{* * * *} \\
(0.009)\end{array}$ \\
\hline LTV & $\begin{array}{r}-0.964 * * * \\
(0.018)\end{array}$ & $\begin{array}{r}-0.766 * * * \\
(0.017)\end{array}$ & $\begin{array}{r}-1.216 * * * \\
(0.017)\end{array}$ & $\begin{array}{r}-1.379 * * * \\
(0.016)\end{array}$ & $\begin{array}{r}-0.925 * * * \\
(0.018)\end{array}$ & $\begin{array}{r}-0.778 * * * \\
(0.016)\end{array}$ \\
\hline (Intercept) & $\begin{array}{r}-0.438^{* * *} \\
(0.121) \\
\end{array}$ & $\begin{array}{r}-4.034 * * * \\
(0.118) \\
\end{array}$ & $\begin{array}{r}-1.513 * * * \\
(0.112) \\
\end{array}$ & $\begin{array}{r}4.173^{* * * *} \\
(0.113) \\
\end{array}$ & $\begin{array}{r}-0.515^{* * *} \\
(0.113) \\
\end{array}$ & $\begin{array}{r}-3.423 * * * \\
(0.108) \\
\end{array}$ \\
\hline $\begin{array}{l}\text { Num. Obs. } \\
\text { R2 }\end{array}$ & $\begin{array}{r}130,851 \\
0.308\end{array}$ & $\begin{array}{r}130,851 \\
0.337\end{array}$ & $\begin{array}{r}130,851 \\
0.321 \\
\end{array}$ & $\begin{array}{r}130,851 \\
0.378\end{array}$ & $\begin{array}{r}130,851 \\
0.308\end{array}$ & $\begin{array}{r}130,851 \\
0.376\end{array}$ \\
\hline
\end{tabular}

Notes: This table reports the results of random effects models for the determinants of the log of mortgage on the list of national culture, urbanization, inflation, interest rates, house price, construction permits, property taxation, bank concentration, GDP, and LTV listed in the first column. Std. Error in parentheses.

$* p<0.1, * * p<0.05, * * * p<0.01$. (See Annex 3. Definitions of variables)

The results show that even after controlling the variables, there is still a strong relationship between cultural dimensions and the amount of mortgage with the same evidence of the baseline model (Table no. 4). In the case of masculinity, the statistically significant level increased to the $1 \%$ level. Regarding the control variables, we found the interest rates, urban population, LTV, and inflation are negatively associated with holding the mortgage, while bank concentration, GDP, house price, construction permits, and property taxation were positively associated. 


\subsection{Endogeneity}

In this section, we re-estimate the specifications of Table no. 5 using a generalized method of moments (GMM) to treat with possible endogeneity of the variables and verify the results of random effects. Following to Diez-Esteban et al. (2019), we used system GMM (an enhanced version of the GMM in which variable differences are also used as instruments in levels by equations). The consistency of the GMM estimators depends on the absence of a second-order serial correlation in the error term using an (AR2) test and the validity of the instruments by the Hansen test of over-identifying restrictions. Therefore, we include the model specification tests in Table no. 6. The estimations of the log of the mortgage that includes all the control variables using GMM models are shown in Table no. 6.

Table no. 6 - Culture and log of mortgage: GMM models

\begin{tabular}{|c|c|c|c|c|c|c|}
\hline & (1) & (2) & (3) & (4) & (5) & (6) \\
\hline Mortgage(t-1) & $\begin{array}{l}0.323^{*} \\
(0.176)\end{array}$ & $\begin{array}{r}0.440 * * * \\
(0.114)\end{array}$ & $\begin{array}{r}-3.393 * * * \\
(0.449)\end{array}$ & $\begin{array}{r}0.751 * * * \\
(0.057)\end{array}$ & $\begin{array}{r}3.203 * * * \\
(0.314)\end{array}$ & $\begin{array}{l}-0.303^{*} \\
(0.159)\end{array}$ \\
\hline IND & $\begin{array}{r}-0.118 * * * \\
(0.038)\end{array}$ & & & & & \\
\hline MAS & & $\begin{array}{r}0.050 * * * \\
(0.009)\end{array}$ & & & & \\
\hline PD & & & $\begin{array}{r}-0.274 * * * \\
(0.033)\end{array}$ & & & \\
\hline LTO & & & & $\begin{array}{r}-0.001 * * * \\
(0.000)\end{array}$ & & \\
\hline UA & & & & & $\begin{array}{r}0.216 * * * \\
(0.024)\end{array}$ & \\
\hline INDUL & & & & & & $\begin{array}{r}0.707 * * * \\
(0.078)\end{array}$ \\
\hline Urbanization & $\begin{array}{r}0.088 * * * \\
(0.027)\end{array}$ & $\begin{array}{r}0.055^{* * * *} \\
(0.009)\end{array}$ & $\begin{array}{r}-0.121 * * * \\
(0.015)\end{array}$ & $\begin{array}{r}0.004 * * * \\
(0.001)\end{array}$ & $\begin{array}{r}0.184 * * * \\
(0.021)\end{array}$ & $\begin{array}{r}-0.321 * * * \\
(0.048)\end{array}$ \\
\hline Inflation & $\begin{array}{l}0.001 * \\
(0.001)\end{array}$ & $\begin{array}{r}-0.001^{* * * *} \\
(0.000)\end{array}$ & $\begin{array}{l}0.001 * \\
(0.001)\end{array}$ & $\begin{array}{r}-0.001^{* * * *} \\
(0.000)\end{array}$ & $\begin{array}{r}-0.004 * * * \\
(0.001)\end{array}$ & $\begin{array}{r}-0.000 \\
(0.000)\end{array}$ \\
\hline Interest rates & $\begin{array}{r}0.003 * * \\
(0.001)\end{array}$ & $\begin{array}{r}-0.000 \\
(0.001)\end{array}$ & $\begin{array}{r}-0.016^{* * * *} \\
(0.002)\end{array}$ & $\begin{array}{r}-0.001^{* * * *} \\
(0.000)\end{array}$ & $\begin{array}{r}0.025 * * * \\
(0.003)\end{array}$ & $\begin{array}{r}-0.003 * * * \\
(0.001)\end{array}$ \\
\hline House price & $\begin{array}{r}0.002 * * * \\
(0.001)\end{array}$ & $\begin{array}{r}-0.005 * * * \\
(0.001)\end{array}$ & $\begin{array}{r}-0.012 * * * \\
(0.001)\end{array}$ & $\begin{array}{r}-0.000 \\
(0.000)\end{array}$ & $\begin{array}{r}0.006 * * * \\
(0.001)\end{array}$ & $\begin{array}{r}-0.000 \\
(0.000)\end{array}$ \\
\hline $\begin{array}{l}\text { Construction } \\
\text { permits }\end{array}$ & $\begin{array}{r}0.063 * * * \\
(0.021)\end{array}$ & $\begin{array}{r}-0.017 * * * \\
(0.004)\end{array}$ & $\begin{array}{r}0.027 * * * \\
(0.008)\end{array}$ & $\begin{array}{l}-0.003^{*} \\
(0.002)\end{array}$ & $\begin{array}{r}0.184 * * * \\
(0.023)\end{array}$ & $\begin{array}{r}-0.051 \\
(0.034)\end{array}$ \\
\hline $\begin{array}{l}\text { Property } \\
\text { taxation }\end{array}$ & $\begin{array}{r}-0.000 \\
(0.000)\end{array}$ & $\begin{array}{r}0.004 * * * \\
(0.001)\end{array}$ & $\begin{array}{r}0.053 * * * \\
(0.006)\end{array}$ & $\begin{array}{r}-0.001 * * * \\
(0.000)\end{array}$ & $\begin{array}{r}-0.043^{* * * *} \\
(0.005)\end{array}$ & $\begin{array}{r}0.007 * * \\
(0.003)\end{array}$ \\
\hline $\begin{array}{l}\text { Bank } \\
\text { concentration }\end{array}$ & $\begin{array}{l}-0.001 \\
(0.000)\end{array}$ & $\begin{array}{r}0.008 * * * \\
(0.001)\end{array}$ & $\begin{array}{r}0.009 * * * \\
(0.001)\end{array}$ & $\begin{array}{r}0.001 * * * \\
(0.000)\end{array}$ & $\begin{array}{r}0.001 * * * \\
(0.000)\end{array}$ & $\begin{array}{r}0.000 \\
(0.000)\end{array}$ \\
\hline GDP & $\begin{array}{r}0.005 * * * \\
(0.001)\end{array}$ & $\begin{array}{r}0.002 * * * * \\
(0.001)\end{array}$ & $\begin{array}{r}0.028 * * * \\
(0.003)\end{array}$ & $\begin{array}{r}0.002^{* * * *} \\
(0.000)\end{array}$ & $\begin{array}{r}-0.013 * * * \\
(0.002)\end{array}$ & $\begin{array}{r}-0.021 * * * * \\
(0.003)\end{array}$ \\
\hline LTV & $\begin{array}{r}0.287 * * * \\
(0.105)\end{array}$ & $\begin{array}{r}-0.213 * * * \\
(0.052)\end{array}$ & $\begin{array}{r}-1.465 * * * \\
(0.163)\end{array}$ & $\begin{array}{r}-0.038 \\
(0.025)\end{array}$ & $\begin{array}{r}1.596 * * * \\
(0.213)\end{array}$ & $\begin{array}{r}0.093 \\
(0.170)\end{array}$ \\
\hline (Intercept) & $\begin{array}{r}3.034 * * * \\
(0.882)\end{array}$ & $\begin{array}{r}-2.136 * * \\
(0.840)\end{array}$ & $\begin{array}{r}46.479 * * * \\
(5.058)\end{array}$ & $\begin{array}{r}1.586 * * * \\
(0.437)\end{array}$ & $\begin{array}{r}-45.030 * * * \\
(5.548) \\
\end{array}$ & $\begin{array}{r}0.000 \\
(0.000) \\
\end{array}$ \\
\hline Jum. Obs. & 59,918 & 59,918 & 59,918 & 59,918 & 59,918 & 59,918 \\
\hline
\end{tabular}




$\begin{array}{lrrrrrr}\text { Wald } & 1.05 \mathrm{e}+06 * * * & 1.58 \mathrm{e}+06 * * * & 1.36 \mathrm{e}+08 * * * & 3.27 \mathrm{e}+06 * * * & 1.17 \mathrm{e}+07 * * * & 24455.35 * * * \\ \text { test(g.l.) } & (11) & (11) & (11) & (11) & (11) & (11) \\ \text { AR1 } & -3.44 * * * & -5.54 * * * & -5.21 * * * & -12.32^{* * *} & -8.33 * * * & -1.08 \\ \text { AR2 } & 0.49 & 0.28 & -1.68 & 1.03 & 1.47 & -1.67 \\ \text { Hansen test } & 22.96(17) & 1.73(1) & 0.10(1) & 23.19(20) & 0.66(1) & 13.90(16) \\ \text { (g.l.) } & & & & & \end{array}$

Notes: This table reports the results of GMM models for the determinants of the log of mortgage on the list of national culture, urbanization, inflation, interest rates, house price, construction permits, property taxation, bank concentration, GDP, and LTV listed in the first column. Std. Error in parentheses.

$* p<0.1, * * p<0.05, * * * p<0.01$. (See Annex 3. Definitions of variables)

The results of GMM models for a log of mortgage in Table no. 6 confirm with random effect models (Table no. 5). Consequently, we found that masculinity, uncertainty avoidance, and indulgence are positively associated with the amount of mortgage and statistically significant at the $1 \%$ level. In contrast, power distance, individualism, and long-term orientation were negatively associated with the amount of mortgage and they are statistically significant at the $1 \%$ level. We accept our hypotheses ( 2 to 4 , and 6 ) related to the "decision to hold secured debt" that suggests that indulgence and masculinity will be positive, while that power distance and long-term orientation will be negative with the decision to hold secured debt. Also, we reject hypotheses $(1$, and 5$)$ that suggest that individualism will be positive, while that uncertainty avoidance will be negative with the decision to hold secured debt. On the contrary to what we found that uncertainty avoidance is positively associated, while individualism is negatively associated with the amount of mortgage. Our findings regarding power distance, long-term orientation, and indulgence are similar to Gaganis et al. (2020).

\subsection{Analysis of the states of financial well-being}

In this section, we examine whether dimensions of national culture are associated with financial well-being. Tables no. 7 and no. 8 present the results of the estimations of the determinants of the households' financial well-being by "afford to pay for the one-week annual holiday", and "the ability to make ends meet" respectively, where we control for the governance effectiveness, GDP, and income.

Table no. 7 - Culture and financial well-being by afford to pay

\begin{tabular}{|c|c|c|c|c|c|c|}
\hline & (1) & (2) & (3) & (4) & (5) & (6) \\
\hline IND & $\begin{array}{r}0.001 * * * \\
(0.000)\end{array}$ & & & & & \\
\hline MAS & & $\begin{array}{r}-0.001 * * * \\
(0.000)\end{array}$ & & & & \\
\hline PD & & & $\begin{array}{r}-0.001 * * * \\
(0.000)\end{array}$ & & & \\
\hline LTO & & & & $\begin{array}{r}0.000 * * * \\
(0.000)\end{array}$ & $-0.005^{* * *}$ & \\
\hline UA & & & & & $(0.000)$ & \\
\hline INDUL & & & & & & $\begin{array}{r}-0.004 * * * \\
(0.000)\end{array}$ \\
\hline GDP & $-0.026^{* * *}$ & $-0.009 * * *$ & $-0.022 * * *$ & $-0.007 * * *$ & $-0.022 * * *$ & $-0.024 * * *$ \\
\hline
\end{tabular}




\begin{tabular}{|c|c|c|c|c|c|c|}
\hline & (1) & (2) & (3) & (4) & (5) & (6) \\
\hline & $(0.002)$ & $(0.002)$ & $(0.001)$ & $(0.002)$ & $(0.001)$ & $(0.001)$ \\
\hline \multirow[t]{2}{*}{ CPI } & $0.023 * * *$ & $0.023 * * *$ & $0.023 * * *$ & $0.022 * * *$ & $0.020 * * *$ & $0.027 * * *$ \\
\hline & $(0.000)$ & $(0.000)$ & $(0.000)$ & $(0.000)$ & $(0.000)$ & $(0.000)$ \\
\hline \multirow[t]{2}{*}{ Income } & $2.094 * * *$ & $2.095 * * *$ & $2.092 * * *$ & $2.126^{* * * *}$ & $2.100 * * *$ & $2.135 * * *$ \\
\hline & (0.004) & $(0.004)$ & $(0.004)$ & $(0.004)$ & $(0.004)$ & (0.004) \\
\hline \multirow[t]{2}{*}{ (Intercept) } & $-0.531 * * *$ & $-0.369 * * *$ & $-0.394 * * *$ & $-0.363 * * *$ & $0.109 * * *$ & $-0.493 * * *$ \\
\hline & $(0.007)$ & $(0.009)$ & $(0.011)$ & $(0.008)$ & $(0.012)$ & $(0.006)$ \\
\hline Num. Obs. & $3,229,429$ & $3,229,429$ & $3,229,429$ & $3,229,429$ & $3,229,429$ & $3,229,429$ \\
\hline AIC & $3,329,943.5$ & $3,329,480.9$ & $3,329,872.5$ & $3,328,999.2$ & $3,326,153.7$ & $3,328,506.9$ \\
\hline BIC & $3,330,008.4$ & $3,329,545.9$ & $3,329,937.4$ & $3,329,064.1$ & $3,326,218.7$ & $3,328,571.8$ \\
\hline Log.Lik. & $-1,664,966.7$ & $-1,664,735.4$ & $-1,664,931.2$ & $-1,664,494.6$ & $-1,663,071.8$ & $-1,664,248.4$ \\
\hline
\end{tabular}

Notes: This table reports the results of logit models for the determinants of the afford to pay for the one-week annual holiday on the list of national culture, GDP, CPI, and income listed in the first column. Std. Error in parentheses. $* p<0.1, * * p<0.05, * * * p<0.01$. (See Annex 3. Definitions of variables)

Table no. 8 - Culture and financial well-being by ends meet

\begin{tabular}{|c|c|c|c|c|c|c|}
\hline & (1) & (2) & (3) & (4) & (5) & (6) \\
\hline IND & $\begin{array}{r}0.010 * * * \\
(0.000)\end{array}$ & & & & & \\
\hline MAS & & $\begin{array}{r}0.003 * * * \\
(0.000)\end{array}$ & & & & \\
\hline PD & & & $\begin{array}{r}-0.004 * * * \\
(0.000)\end{array}$ & & & \\
\hline LTO & & & & $\begin{array}{r}0.002 * * * \\
(0.000)\end{array}$ & & \\
\hline UA & & & & & $\begin{array}{r}-0.008 * * * \\
(0.000)\end{array}$ & \\
\hline INDUL & & & & & & $\begin{array}{r}0.002 * * * * \\
(0.000)\end{array}$ \\
\hline GDP & $\begin{array}{r}-0.000 * * * \\
(0.000)\end{array}$ & $\begin{array}{r}-0.000 * * * \\
(0.000)\end{array}$ & $\begin{array}{r}-0.000 * * * \\
(0.000)\end{array}$ & $\begin{array}{r}-0.000 * * * \\
(0.000)\end{array}$ & $\begin{array}{r}-0.000 * * * \\
(0.000)\end{array}$ & $\begin{array}{r}-0.000 \\
(0.000)\end{array}$ \\
\hline CPI & $\begin{array}{r}0.054 * * * \\
(0.000)\end{array}$ & $\begin{array}{r}0.060 * * * \\
(0.000)\end{array}$ & $\begin{array}{r}0.055 * * * \\
(0.000)\end{array}$ & $\begin{array}{r}0.061 * * * \\
(0.000)\end{array}$ & $\begin{array}{r}0.052 * * * \\
(0.000)\end{array}$ & $\begin{array}{r}0.057 * * * * \\
(0.000)\end{array}$ \\
\hline Income & $\begin{array}{r}0.000 * * * \\
(0.000)\end{array}$ & $\begin{array}{r}0.000 * * * \\
(0.000)\end{array}$ & $\begin{array}{r}0.000 * * * \\
(0.000)\end{array}$ & $\begin{array}{r}0.000 * * * \\
(0.000)\end{array}$ & $\begin{array}{r}0.000 * * * \\
(0.000)\end{array}$ & $\begin{array}{r}0.000 * * * * \\
(0.000)\end{array}$ \\
\hline Num. Obs. & $3,414,075$ & $3,414,075$ & $3,414,075$ & $3,414,075$ & $3,414,075$ & $3,414,075$ \\
\hline AIC & $10,641,925.5$ & $10,666,014.0$ & $10,666,203.3$ & $10,636,804.2$ & $10,652,871.0$ & $10,669,208.4$ \\
\hline BIC & $10,642,056.0$ & $10,666,144.5$ & $10,666,333.8$ & $10,636,934.7$ & $10,653,001.5$ & $10,669,338.9$ \\
\hline Log.Lik. & $-5,320,952.7$ & $-5,332,997$ & $-5,333,091.7$ & $-5,318,392.1$ & $-5,326,425.5$ & $-5,334,594.2$ \\
\hline
\end{tabular}

Tables no. 7 and no. 8 show that individualism and long-term orientation are positively associated with financial well-being based on the afford to pay for a one-week annual holiday, and ability to make ends meet that are statistically significant at a $1 \%$ level. Whereas the power distance and uncertainty avoidance were negatively associated with financial wellbeing based on two measurements and they are statistically significant at a $1 \%$ level. Also, we found mixed results in the case of masculinity and indulgence based on two measurements. 
Regarding control variables, we found governance effectiveness and income are positively associated with financial well-being based on two measurements, while the GDP was negatively associated.

We accept our hypotheses ( 7 to 9 ) related to financial well-being that suggests the power distance and uncertainty avoidance will be negative, while individualism will be positively associated with financial well-being. Moreover, we cannot decide regarding hypothesis (10) due to mixed results. However, we found new evidence regarding long-term orientation that is positively associated with financial well-being. Our findings regarding power distance, and individualism are consistent with Steel et al. (2018), while the uncertainty avoidance is similar to Hofstede (2001) and Steel et al. (2018).

\section{DISCUSSION}

Some of our results are consistent with the existing literature e.g., the results of individualism, indulgence, power distance, uncertainty avoidance, and long-term orientation with a decision to hold a mortgage are consistent with Gaganis et al. (2020), the findings related to power distance, and individualism with financial well-being are consistent with Steel et al. (2018) and the finding related to the uncertainty avoidance with financial wellbeing is similar to the Hofstede (2001) and Steel et al. (2018) argument. Also, the finding of long-term orientation corresponds with de Mooij and Hofstede (2002) that indicates that longterm orientated cultures are cash or debit card cultures, not credit card cultures. Additionally, some results challenge previous findings that suggest there is no significant relationship between masculinity and mortgage debt such as Gaganis et al. (2020), instead of that we found a negative relationship between masculinity and the decision to hold a mortgage. Also, our results offer new evidence regarding long-term orientation that is positively associated with financial well-being.

\section{CONCLUSION}

This research extends the literature on household finance by reinforcing the knowledge on the determinants of mortgage and financial well-being levels. We examined the influence of Hofstede's national culture on a mortgage and financial well-being in 31 European countries. We found that power distance, masculinity, uncertainty avoidance, and long-term orientation are negatively associated with holding a mortgage in contrast to individualism and indulgence. We also found that masculinity, uncertainty avoidance, and indulgence are positively associated with the amount of mortgage in contrast to power distance, individualism, and long-term orientation. Moreover, we discovered that individualism and long-term orientation are positively associated with financial well-being. While the power distance and uncertainty avoidance were negatively associated with financial well-being.

This study investigates the implications of national culture on mortgages and financial welfare to households, policymakers, and academia. The results of this study are beneficial to the households to provide them with the needed knowledge to understand the way the culture affects their decision to hold a mortgage and financial welfare. This might help the households to make effective decisions such as when to hold a mortgage, the amount of this mortgage, raise their awareness of how to deal with their national culture to have a higher level of financial well-being, providing them with the ability to plan ahead of time for their financial 
issues, and thus they might be able to avoid having any financial distress. Moreover, we provide policymakers with important information to manage the mortgage process by offering more promotions and facilitating these procedures to encourage the societies with high power distance, masculinity, uncertainty avoidance, and long-term orientation to hold more mortgages and enhance the welfare of households in the societies with high power distance and uncertainty avoidance. Lastly, this study adds to the academic research on the determinants of the decision to hold secured debts and a better explanation of the states of financial well-being. Future research can investigate the relationship between national culture and household finance in different settings on other continents.

\section{Acknowledgements}

We are grateful to Eurostat for offering the EU-SILC dataset, the "Global Platform for Higher Education in Emergencies-Portugal" for funding the main author, and to the former President Jorge Sampaio and Professor Helena Barroco for their continued support. This research has been financed by Portuguese public funds through FCT - Fundação para a Ciência e a Tecnologia, I.P., in the framework of the project with reference UIDB/04105/2020.

\section{ORCID}

Rashed Isam Ashqar iD http://orcid.org/0000-0001-5078-5449

Júlio Lobão iD http://orcid.org/0000-0001-5896-9648

\section{References}

Aggarwal, R., and Goodell, J. W., 2014. Cross-National Differences in Access to Finance: Influence of Culture and Institutional Environments. Research in International Business and Finance, 31, 193211.

Aggarwal, R., Kearney, C., and Lucey, B., 2012. Gravity and Culture in Foreign Portfolio Investment. Journal of Banking \& Finance, 36(2), 525-538. http://dx.doi.org/10.1016/j.jbankfin.2011.08.007

Ahuvia, A. C., 2002. Individualism/Collectivism and Cultures of Happiness: A Theoretical Conjecture on the Relationship between Consumption, Culture and Subjective Well-Being at the National Level. Journal of Happiness Studies, 3(1), 23-36. http://dx.doi.org/10.1023/A:1015682121103

Arrindell, W. A., 1998. Femininity and Subjective Well-Being. In G. H. Hofstede (Ed.), Masculinity and Femininity: The Taboo Dimension of National Cultures (pp. 44-54): SAGE.

Arrindell, W. A., Hatzichristou, C., Wensink, J., Rosenberg, E., van Twillert, B., Stedema, J., and Meijer, D., 1997. Dimensions of National Culture as Predictors of Cross-National Differences in Subjective Well-Being. Personality and Individual Differences, 23(1), 37-53. http://dx.doi.org/10.1016/S01918869(97)00023-8

Badev, A., Beck, T., Vado, L., and Walley, S., 2014. Housing Finance across Countries: New Data and Analysis. Policy Research Working Papers, January. https://elibrary.worldbank.org/doi/abs/10.1596/1813-9450-6756. http://dx.doi.org/10.1596/18139450-6756

Breuer, W., Hens, T., Salzmann, A. J., and Wang, M., 2015. On the Determinants of Household Debt $\begin{array}{llll}\text { Maturity } & \text { Choice. } & \text { Applied } & \text { 479onomics, }\end{array}$ http://dx.doi.org/10.1080/00036846.2014.972547

Breuer, W., Riesener, M., and Salzmann, A. J., 2014. Risk Aversion vs. Individualism: What Drives Risk Taking in Household Finance? European Journal of Finance, 20(5), 446-462. http://dx.doi.org/10.1080/1351847X.2012.714792 
Brown, M., Henchoz, C., and Spycher, T., 2018. Culture and Financial Literacy: Evidence from a withinCountry Language Border. Journal of Economic Behavior \& Organization, 150(June), 62-85. http://dx.doi.org/10.1016/j.jebo.2018.03.011

Brown, S., Garino, G., and Taylor, K., 2008. Mortgages and Financial Expectations: A Household-Level Analysis. Southern Economic Journal, 74(3), 857-878. http://dx.doi.org/10.1002/j.23258012.2008.tb00868.x

Brown, S., Garino, G., and Taylor, K., 2013. Household Debt and Attitudes toward Risk. Review of Income and Wealth, 59(2), 283-304. http://dx.doi.org/10.1111/j.1475-4991.2012.00506.x

Brown, S., and Taylor, K., 2014. Household Finances and the 'Big Five'Personality Traits. Journal of Economic Psychology, 45(December), 197-212. http://dx.doi.org/10.1016/j.joep.2014.10.006

Cerutti, E., Claessens, S., and Laeven, L., 2017. The Use and Effectiveness of Macroprudential Policies: New Evidence. Journal of Financial Stability, 28(February), 203-224. http://dx.doi.org/10.1016/j.jfs.2015.10.004

Chang, C. H., and Lin, S. J., 2015. The Effects of National Culture and Behavioral Pitfalls on Investors' Decision-Making: Herding Behavior in International Stock Markets. International Review of Economics \& Finance, 37(May), 380-392. http://dx.doi.org/10.1016/j.iref.2014.12.010

Chatterjee, D., Kumar, M., and Dayma, K. K., 2019. Income security, social comparisons and materialism. International Journal of Bank Marketing, 37(4), 1041-1061. http://dx.doi.org/10.1108/IJBM-042018-0096

Christen, M., and Morgan, R., 2005. Keeping Up With the Joneses: Analyzing the Effect of Income Inequality on Consumer Borrowing. Quantitative Marketing and Economics (QME), 3(2), 145-173. http://dx.doi.org/10.1007/s11129-005-0351-1

Chui, A. C. W., Kwok, C. C. Y., and Zhou, G., 2016. National culture and the cost of debt. Journal of Banking \& Finance, 69(August), 1-19. http://dx.doi.org/10.1016/j.jbankfin.2016.04.001

de Mooij, M., and Hofstede, G., 2002. Convergence and Divergence in Consumer Behavior: Implications for International Retailing. Journal of Retailing, 78(1), 61-69. http://dx.doi.org/10.1016/S00224359(01)00067-7

Diener, E., Diener, M., and Diener, C., 2009. Factors Predicting the Subjective Well-Being of Nations Culture and Well-Being (pp. 43-70): Springer. http://dx.doi.org/10.1007/978-90-481-2352-0_3

Diener, E., Oishi, S., and Lucas, R. E., 2003. Personality, Culture, and Subjective Well-Being: Emotional and Cognitive Evaluations of Life. Annual Review of Psychology, 54(1), 403-425. http://dx.doi.org/10.1146/annurev.psych.54.101601.145056

Diez-Esteban, J. M., Farinha, J. B., and Garcia-Gomez, C. D., 2019. Are Religion and Culture Relevant for Corporate Risk-Taking? International Evidence. BRQ Business Research Quarterly, 22(1), 36-55. http://dx.doi.org/10.1016/j.brq.2018.06.003

Donnelly, G., Iyer, R., and Howell, R. T., 2012. The Big Five personality traits, material values, and financial well-being of self-described money managers. Journal of Economic Psychology, 33(6), 1129-1142.

Fazli Sabri, M., Cook, C. C., and Gudmunson, C. G., 2012. Financial well-being of Malaysian college students. Asian Education and Development Studies, 1(2), 153-170. http://dx.doi.org/10.1108/20463161211240124

Fischer, R., and Boer, D., 2011. What is more important for national well-being: Money or autonomy? A meta-analysis of well-being, burnout, and anxiety across 63 societies. Journal of Personality and Social Psychology, 101(1), 164-184. http://dx.doi.org/10.1037/a0023663

Fligstein, N., Hastings, O. P., and Goldstein, A., 2017. Keeping up with the Joneses: How Households Fared in the Era of High Income Inequality and the Housing Price Bubble, 1999-2007. Socius, 3, 2378023117722330. http://dx.doi.org/10.1177/2378023117722330

Fuseini, K., Kalule-Sabiti, I., and Lwanga, C., 2019. Dynamics of Women's Autonomy in Household Decision-Making in Ghana. Journal of Comparative Family Studies, 50(4), 293-312. http://dx.doi.org/10.3138/jcfs.50.4.002 
Gaganis, C., Hasan, I., and Pasiouras, F., 2020. National Culture and Housing Credit. Journal of Empirical Finance, 56, 19-41. http://dx.doi.org/10.1016/j.jempfin.2019.12.003

Gogolin, F., Dowling, M., and Cummins, M., 2017. Individual Values and Household Finances. Applied Economics, 49(35), 3560-3578. http://dx.doi.org/10.1080/00036846.2016.1262528

Guiso, L., Sapienza, P., and Zingales, L., 2006. Does Culture Affect Economic Outcomes? The Journal of Economic Perspectives, 20(2), 23-48. http://dx.doi.org/10.1257/jep.20.2.23

Guiso, L., and Sodini, P., 2013. Household Finance: An Emerging Field Handbook of the Economics of Finance (pp. 1397-1532): Elsevier.

Hofstede, G., 1983. The Cultural Relativity of Organizational Practices and Theories. Journal of International Business Studies, 14(2), 75-89. http://dx.doi.org/10.1057/palgrave.jibs.8490867

Hofstede, G., 2001. Culture's Consequences: Comparing Values, Behaviors, Institutions, and Organizations Across Nations (2nd ed.). Thousand Oaks, CA: Sage.

Hofstede, G., 2011. Dimensionalizing Cultures: The Hofstede Model in Context. Online Readings in Psychology and Culture, 2(1), 919-2307. http://dx.doi.org/10.9707/2307-0919.1014

Hofstede, G., Hofstede, G. J., and Minkov, M., 2005. Cultures and Organizations: Software of the Mind (vol 2). New York: Mcgraw-hill

Kanagaretnam, K., Lobo, G. J., Wang, C., and Whalen, D. J., 2015. Religiosity and risk-taking in international banking. Journal of Behavioral and Experimental Finance, 7 (C), 42-59. http://dx.doi.org/10.1016/j.jbef.2015.07.004

Mahdzan, N. S., Zainudin, R., Mohd, E. A. S., Zainir, F., and Wan, M. W. A., 2019. Determinants of Subjective Financial Well-Being across Three Different Household Income Groups in Malaysia. Social Indicators Research, 146(3), 699-726. http://dx.doi.org/10.1007/s11205-019-02138-4

Nyhus, E. K., and Webley, P., 2001. The Role of Personality in Household Saving and Borrowing Behaviour. European Journal of Personality, 15, S85-S103. http://dx.doi.org/10.1002/per.422

Oishi, S., Kesebir, S., and Diener, E., 2011. Income inequality and happiness. Psychological Science, 22(9), 1095-1100. http://dx.doi.org/10.1177/0956797611417262

Penaloza, L., and Barnhart, M., 2011. Living US Capitalism: The Normalization of Credit/Debt. The Journal of Consumer Research, 38(4), 743-762. http://dx.doi.org/10.1086/660116

Rodriguez-Planas, N., 2018. Mortgage Finance and Culture. Journal of Regional Science, 58(4), 786-821. http://dx.doi.org/10.1111/jors.12385

Steel, P., Taras, V., Uggerslev, K., and Bosco, F., 2018. The Happy Culture: A Theoretical, Meta-Analytic, and Empirical Review of the Relationship Between Culture and Wealth and Subjective Well-Being. $\begin{array}{llll}\text { Personality and Social Psychology Review, 22(2), 128-169. } & \text {. }\end{array}$ http://dx.doi.org/10.1177/1088868317721372

Tajaddini, R., and Hassan, F. G., 2017. National Culture and Default on Mortgages. International Review of Finance, 17(1), 107-133.

Wolswijk, G., 2006. Determinants of Mortgage Debt Growth in EU Countries. European Journal of Housing Policy, 6(2), 131-149. http://dx.doi.org/10.1080/14616710600787627

Wooldridge, J. M., 2010. Econometric Analysis of Cross Section and Panel Data Retrieved from https://mitpress.mit.edu/books/econometric-analysis-cross-section-and-panel-data-second-edition

Xu, Y., Beller, A. H., Roberts, B. W., and Brown, J. R., 2015. Personality and young adult financial distress. Journal of Economic Psychology, 51, 90-100. http://dx.doi.org/10.1016/j.joep.2015.08.010

\section{ANNEX 1}

\section{Supplementary data}

Supplementary data to this article can be found online under official request the Eurostat database at https://ec.europa.eu/eurostat/web/microdata/european-union-statistics-on-income-and-living-conditions and in other open datasets are shown in Annex 3. 


\section{ANNEX 2}

Distribution of the sample by country

\begin{tabular}{ccc}
\hline Countries & $\begin{array}{c}\text { Num. of } \\
\text { obs. }\end{array}$ & $\begin{array}{c}\text { Respective } \\
\text { \% }\end{array}$ \\
\hline Austria & 88,817 & $2.59 \%$ \\
\hline Belgium & 89,004 & $2.59 \%$ \\
\hline Bulgaria & 69,422 & $2.02 \%$ \\
\hline $\begin{array}{c}\text { Czech } \\
\text { Republic }\end{array}$ & 119,535 & $3.48 \%$ \\
\hline Denmark & 87,361 & $2.54 \%$ \\
\hline Germany & 185,285 & $5.40 \%$ \\
\hline Estonia & 79,673 & $2.32 \%$ \\
\hline Greece & 145,121 & $4.23 \%$ \\
\hline Croatia & 57,118 & $1.66 \%$ \\
\hline Spain & 196,498 & $5.72 \%$ \\
\hline France & 163,293 & $4.76 \%$ \\
\hline Ireland & 77,492 & $2.26 \%$ \\
\hline Italy & 309,187 & $9.01 \%$ \\
\hline Latvia & 79,411 & $2.31 \%$ \\
\hline Lithuania & 69,781 & $2.03 \%$ \\
\hline Hungary & 125,798 & $3.66 \%$ \\
\hline & &
\end{tabular}

\begin{tabular}{crr}
\hline Countries & $\begin{array}{c}\text { Num. of } \\
\text { obs. }\end{array}$ & $\begin{array}{c}\text { Respective } \\
\text { \% }\end{array}$ \\
\hline Malta & 47,508 & $1.38 \%$ \\
\hline Netherlands & 148,100 & $4.31 \%$ \\
\hline Poland & 189,901 & $5.53 \%$ \\
\hline Portugal & 103,376 & $3.01 \%$ \\
\hline Romania & 91,107 & $2.65 \%$ \\
\hline Slovenia & 125,528 & $3.66 \%$ \\
\hline Finland & 158,965 & $4.63 \%$ \\
\hline Sweden & 96,787 & $2.82 \%$ \\
\hline Iceland & 38,250 & $1.11 \%$ \\
\hline Norway & 89,614 & $2.61 \%$ \\
\hline Serbia & 34,265 & $1.00 \%$ \\
\hline Switzerland & 87,471 & $2.55 \%$ \\
\hline United & & \\
Kingdom & 142,209 & $4.14 \%$ \\
\hline Luxembourg & 62,077 & $1.81 \%$ \\
\hline Slovakia & 75,305 & $2.19 \%$ \\
\hline Total & $\mathbf{3 , 4 3 3 , 2 5 9}$ & $\mathbf{1 0 0 . 0 0 \%}$ \\
\hline
\end{tabular}

\section{ANNEX 3}

\section{Definitions of variables}

\begin{tabular}{|c|c|}
\hline Variable & Definition \\
\hline \multicolumn{2}{|l|}{ Dependent Variables } \\
\hline Holding mortgage & $\begin{array}{l}\text { Measured as a binary variable takes the value of } 1 \text { if the individual is holding a mortgage, } \\
\text { otherwise, the value is } 0 \text {. (Source: EU-SILC dataset, Eurostat). }\end{array}$ \\
\hline $\begin{array}{l}\text { Log of total } \\
\text { mortgage }\end{array}$ & $\begin{array}{l}\text { The logarithm of mortgage principal repayment plus interest mortgage in Euro currency. } \\
\text { (Source: EU-SILC dataset, Eurostat). }\end{array}$ \\
\hline $\begin{array}{l}\text { Ability to make ends } \\
\text { meet }\end{array}$ & $\begin{array}{l}\text { Financial well-being Indicator which takes the values as follows: } 1 \text { with great difficulty, } 2 \\
\text { with difficulty, } 3 \text { with some difficulty, } 4 \text { fairly easily, } 5 \text { easily, } 6 \text { very easily. (Source: EU- } \\
\text { SILC dataset, Eurostat). }\end{array}$ \\
\hline $\begin{array}{l}\text { Capacity afford to } \\
\text { pay for a one-week } \\
\text { annual holiday }\end{array}$ & $\begin{array}{l}\text { The financial well-being Indicator is measured as a binary variable that takes the value of } 1 \\
\text { if the answer is yes, otherwise, and } 0 \text { if it is no. (Source: EU-SILC dataset, Eurostat). }\end{array}$ \\
\hline \multicolumn{2}{|c|}{ Independent Variables } \\
\hline Power distance (PD) & $\begin{array}{l}\text { National Culture Indicator expresses the degree to which the less powerful members of a } \\
\text { society accept and expect that power is distributed unequally. (Source: Hofstede Insights). }\end{array}$ \\
\hline Individualism (IND) & $\begin{array}{l}\text { National Culture Indicator of the degree to which individuals are expected to take care of } \\
\text { only themselves and their immediate families. (Source: Hofstede Insights). }\end{array}$ \\
\hline Masculinity (MAS) & $\begin{array}{l}\text { National Culture Indicator that represents a preference in society for achievement, heroism, } \\
\text { assertiveness, and material rewards for success. Society at large is more competitive. } \\
\text { (Source: Hofstede Insights). }\end{array}$ \\
\hline $\begin{array}{l}\text { Uncertainty } \\
\text { avoidance (UA) }\end{array}$ & $\begin{array}{l}\text { National Culture Indicator that expresses the degree to which the members of a society feel } \\
\text { uncomfortable with uncertainty and ambiguity. (Source: Hofstede Insights). }\end{array}$ \\
\hline $\begin{array}{l}\text { Long-term } \\
\text { orientation (LTO) }\end{array}$ & $\begin{array}{l}\text { National Culture Indicator that relates to the choice of focus for people's efforts: the future } \\
\text { or the present and past. (Source: Hofstede Insights). }\end{array}$ \\
\hline $\begin{array}{l}\text { Indulgence } \\
\text { (INDUL) }\end{array}$ & $\begin{array}{l}\text { National Culture Indicator stands for a society that allows relatively free gratification of basic } \\
\text { and natural human drives related to enjoying life and having fun. (Source: Hofstede Insights). }\end{array}$ \\
\hline \multicolumn{2}{|l|}{ Control Variables } \\
\hline GDP & GDP growth (annual \%). (Source: EMF Hypostat). \\
\hline Inflation & Inflation, consumer prices (annual \%). (Source: EMF Hypostat). \\
\hline
\end{tabular}




\begin{tabular}{|c|c|}
\hline Variable & Definition \\
\hline Interest rates & $\begin{array}{l}\text { Representative Interest Rates on New Residential Loans, annual average based on monthly } \\
\text { figures, percent. (Source: EMF Hypostat). }\end{array}$ \\
\hline House price & Nominal House Price Indices. (Source: EMF Hypostat). \\
\hline Urbanization & Urban population (\% of total). (Source: World Development Indicators of the World Bank). \\
\hline Bank concentration & $\begin{array}{l}\text { Assets of the three largest commercial banks as a share of total commercial banking assets } \\
\text { (\%). (Source: Global Financial Development Database of the World Bank). }\end{array}$ \\
\hline Construction permits & $\begin{array}{l}\text { A number of procedures are required for a business in the construction industry to build a } \\
\text { warehouse. (Source: Doing Business Report of the World Bank). }\end{array}$ \\
\hline Tax property & $\begin{array}{l}\text { Tax on the property as a percentage of GDP. Tax on the property is defined as recurrent and } \\
\text { non-recurrent taxes on the use, ownership, or transfer of property. (Source: OECD) }\end{array}$ \\
\hline $\begin{array}{l}\text { Governmental } \\
\text { effectiveness (CPI) }\end{array}$ & tion Perception Index (CPI). (Sou \\
\hline LTV & $\begin{array}{l}\text { Dummy variable that takes the value of } 1 \text { if there is a Loan-to-Value Ratio macroprudential } \\
\text { instrument and the value of } 0 \text { otherwise. (Source: Cerutti et al., 2017). }\end{array}$ \\
\hline Income & Total gross household income in Euro currency. (Source: EU-SILC dataset, Eurostat). \\
\hline
\end{tabular}

\section{ANNEX 4}

\section{Correlation coefficients of cultural dimensions}

\begin{tabular}{|c|c|c|c|c|c|c|}
\hline & PD & MAS & IND & INDUL & LTO & UA \\
\hline PD & 1 & & & & & \\
\hline MAS & $0.168 * * *$ & 1 & & & & \\
\hline IND & $-0.556 * * *$ & $0.186 * * *$ & 1 & & & \\
\hline INDUL & $-0.543 * * *$ & $-0.216 * * *$ & $0.312 * * *$ & 1 & & \\
\hline LTO & $0.005 * * *$ & $0.228 * * *$ & $0.227 * * *$ & $-0.289 * * *$ & 1 & \\
\hline UA & $0.663 * * *$ & $0.214 * * *$ & $-0.559 * * *$ & $-0.508 * * *$ & $0.005 * * *$ & 1 \\
\hline
\end{tabular}

Notes: This table reports the correlation coefficients of cultural dimensions. $* p<0.1$, ** $p<0.05$, *** $p<$ 0.01. (See Annex 3. Definitions of variables)

\section{Notes}

${ }^{1}$ All the amounts denominated in currencies other than the euro were converted to the euro at the average exchange rate for each specified year.

226 member countries of the EU (Austria, Belgium, Bulgaria, Czech Republic, Denmark, Germany, Estonia, Greece, Croatia, Spain, France, Ireland, Italy, Latvia, Lithuania, Luxembourg, Hungary, Malta, Netherlands, Austria, Poland, Portugal, Romania, Slovenia, Finland, and Sweden) and 5 other European countries (Iceland, Norway, Serbia, Switzerland, and the United Kingdom).

\section{Copyright}

c) (i) $(-)$ This article is an open access article distributed under the terms and conditions of the EY NG ND Creative Commons Attribution-NonCommercial-NoDerivatives 4.0 International License. 